\title{
Young hospital pharmacists' job stress and career prospects amidst the COVID-19 pandemic in China
}

\author{
Jiahao Wu ${ }^{1,2}$, Jian Cai ${ }^{1,3}$, Ming Fang ${ }^{1}$, Yan Wang ${ }^{1}$ and Feng $\mathrm{Xu}^{1{ }^{*}}$ (1)
}

\begin{abstract}
Background: Coronavirus disease (COVID-19) pandemic posed a critical threat to public health in the past year and has not been fully controlled so far. The nature of front-line young hospital pharmacists' occupation puts them at an increased risk of contracting any contagious disease, including COVID-19. Recent survey indicated that hospital pharmacists in China are depressive, hostile amid the pandemic.

Aim: The present investigation aims to understand the job stress among young hospital pharmacists during the outbreak of COVID-19 and to provide basic information for pharmacy managers to help young fellows to cope with job stress.

Method: This study is adopting pharmacist job stress questionnaire as the key instrument of data collection through WJX App in mobile phone. Demographic information, career prospects and stress management proposals were obtained synchronously. Quantitative data were processed with SPSS. Significant differences were examined using analysis of variance and Chi-square analysis.

Result: About $60 \%$ of 289 questionnaire respondents complained of job stress (178 respondents). According to the narrative description of the data, young pharmacists' gender, education background, hospital grade, and specific work post had no significant effect on job stress difference. However, young pharmacists in different age-groups and professional titles showed different job stress. Pharmacists at the age of 31-35 complained more stress than the others. Pharmacists with high professional title (deputy chief pharmacist) complained more stress than the others. About $65 \%$ of 289 respondents had long-term plan for their practice, although $61 \%$ of young pharmacists felt troubled or worried with their future. As for stress management proposal, almost all young pharmacists hoped to improve their professional identity via raising their wages.
\end{abstract}

Conclusion: More than half of young pharmacists suffer from job stress amidst the COVID-19 pandemic in China, and various intervention measures should be taken to relieve the stress and finally improve their social identity.

Keywords: COVID-19, Young pharmacists, Job stress, Intervention, China

*Correspondence: xuf@smu.edu.cn

${ }^{1}$ Fengxian Hospital, Southern Medical University, Shanghai, China

Full list of author information is available at the end of the article

\section{Background}

Currently, young hospital pharmacists face various heavy work demands, work-life conflicts, irregular work arrangements and heavy work pressure in China [1,2]. To make matters worse, coronavirus disease (COVID19) pandemic was a critical threat to public health in the past year or so and has not been fully controlled so far. original author(s) and the source, provide a link to the Creative Commons licence, and indicate if changes were made. The images or other third party material in this article are included in the article's Creative Commons licence, unless indicated otherwise in a credit line to the material. If material is not included in the article's Creative Commons licence and your intended use is not permitted by statutory regulation or exceeds the permitted use, you will need to obtain permission directly from the copyright holder. To view a copy of this licence, visit http://creativecommons.org/licenses/by/4.0/. The Creative Commons Public Domain Dedication waiver (http://creativeco mmons.org/publicdomain/zero/1.0/) applies to the data made available in this article, unless otherwise stated in a credit line to the data. 
Latest news cites that Chinese mainland reports 27 new COVID-19 cases, with 20 locally transmitted in Guangdong, and the results of detected gene sequencing in all infected patients in Guangzhou's latest outbreak are homologous, all from variants detected in India [3]. The nature of hospital pharmacists' occupation puts them at an increased risk of getting any contagious COVID-19 [4]. Young pharmacists are usually on the front-line of the COVID-19 outbreak response and as such are more at risk of contracting this virus [5]. Besides, as social distancing and non-essential businesses are implemented to control the physical spread of COVID-19, these challenging measures increased stress, anxiety, depressive symptoms, and exacerbation of pre-existing mental illness [6]. Recent surveys reported negative psychological effects were induced by COVID-19 pandemic, which included stress, fear, anxiety, depression, burnout, hostility, and mental exhaustion in hospital pharmacists in China [7, 8].

Evidences showed that young pharmacists' job identity and self-satisfaction have been at a low level in China [9-11]. On the one hand, job burnout (such as repeated drug dispensing from day to day), lack of sense of accomplishment and low social position (compared with medical doctors in hospital) contributed to the low level [12]. On the other hand, the low income of young pharmacists has a great negative influence on their good life. Before year of 2017, there was still 15\% drug price bonus in medical institution in China. At that time pharmacists were regarded as money-maker for hospital and they got more pay from hospital. Now, circumstances change with the passage of time. Drug price bonus in hospital is zero. The salary of hospital pharmacists has been greatly reduced. Low income brings about their survival challenge, and impairs their physical and mental health [13]. Last but not least, pharmacists especially young dispensing fellows face the challenge of professional transformation from simply dispensing to providing clinical pharmacy service. Many young dispensing pharmacists even have sprouted their intention to resign in the new context of COVID-19 pandemic. In short, as the health care system in China is different from that of other countries, the characteristics of pharmacist job stress might be different from that of other countries $[14,15]$. Thus it is necessary to clarify the current situation of job stress among Chinese young hospital pharmacists during the outbreak of COVID-19. This work aims to provide basic information for pharmacy managers to help young fellows to cope with job stress.

\section{Methods}

All data are divided into four sections and collected through WJX App in mobile phone. The first section was the demographic information of the respondents. The second section was job stress questionnaire. We adopted the validated pharmacist job stress questionnaire scale as the key instrument [16], which was composed of 12 job stress-related questions based on the various elements of the work (workload, work time, salary, relations with colleagues and leader, etc.) with five-level Likert scale (from strongly disagree, disagree, neutral, agree, to strongly agree, respectively, and grades assigning from 1 to 5 points, respectively). For each respondent the total score ranged from the minimum 12 to the maximum 60 points. The higher the sum value, the greater the job stresses. The third section dealt with personal viewpoints on profession development prospects. The fourth section was free comments on stress management proposals.

The survey was conducted from August 1 through September 30, 2020. Each mobile phone account is only allowed to submit once in order to avoid submitting questionnaires repeatedly. The study sample is young hospital pharmacists under the age of 35 years who work in the medical institutions at all levels in China. Participation was voluntary, and the responses were anonymous and no identifiable information was collected. Data differences were examined using analysis of variance and Chi-square test.

\section{Results}

\section{Demographic data}

A total of 289 survey respondents were effectively recovered with 219 females. 32 pharmacists were less than 25 years old and 153 pharmacists were over 31 years old. Among them, 213 pharmacists were assistant pharmacist or pharmacist, and only 5 pharmacists were deputy chief pharmacist. The other relevant demographic information and practice information of the respondents are given in Table 1.

\section{Job stress data}

Based on scale assignment statistics, score less than 24 points is regarded as no much job stress, score between 24 and 36 points is regarded as certain job stress, and score more than 36 points is regarded as higher job stress. In this survey, 18 respondents $(6.23 \%)$ claimed they do not feel too much job stress (6.23\%), 93 respondents $(32.18 \%)$ felt a certain job stress, and 178 respondents (61.59\%) expressed higher job stress (Fig. 1). 
Table 1 Demographic information and practice information of the respondents

\begin{tabular}{lc}
\hline Variable & Quantity \\
\hline Gender & \\
Male & $70(24.22 \%)$ \\
Female & $219(75.78 \%)$ \\
Age & \\
Less than 25 & $32(11.07 \%)$ \\
$26-30$ & $104(35.99 \%)$ \\
$31-35$ & $153(52.94 \%)$ \\
Education background & \\
Associate degree and below & $40(13.84 \%)$ \\
Bachelor degree & $196(67.82 \%)$ \\
Master degree or above & $53(18.34 \%)$ \\
Hospital grade & \\
Level 1 & $42(14.53 \%)$ \\
Level 2 & $44(15.22 \%)$ \\
Level 3 & $203(70.24 \%)$ \\
Professional title & \\
Assistant pharmacist & $40(13.84 \%)$ \\
Pharmacist & $173(59.86 \%)$ \\
Pharmacist-in-charge & $71(24.57 \%)$ \\
Deputy chief pharmacist & $5(1.73 \%)$ \\
Chief pharmacist & $0(0 \%)$ \\
Specific work post & \\
Dispensing pharmacy & $190(65.74 \%)$ \\
Clinical pharmacy service & $55(19.03 \%)$ \\
Pharmacy intravenous admixture services & $28(9.69 \%)$ \\
Other work posts & $16(5.54 \%)$ \\
\hline &
\end{tabular}

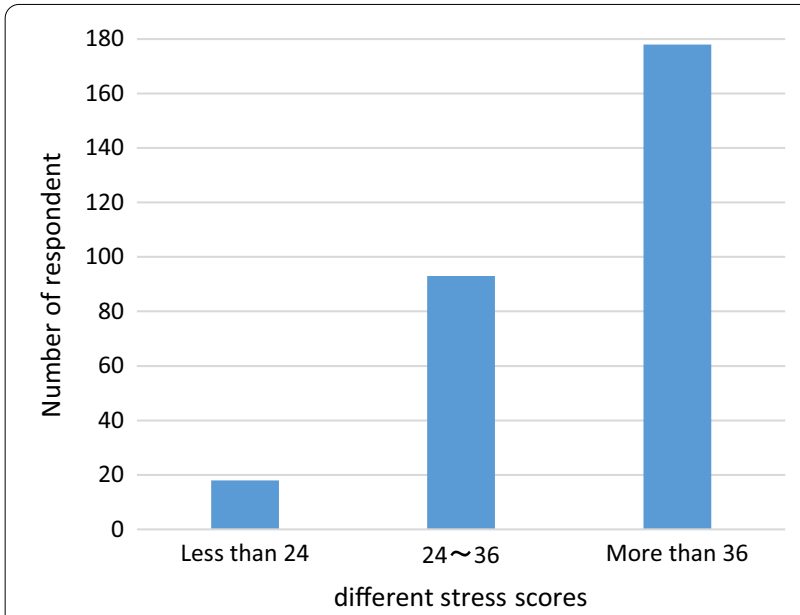

Fig. 1 Varying degree job stress distribution of young pharmacists
Job stress vs gender, age, education background, hospital grade, professional title and specific work post

Our data (Table 2) showed that no gender, education background, hospital grade and specific work post differences in the job stress among young pharmacists in this survey. However, different age and different professional titles indicated a certain association with job stress. On one hand, young hospital pharmacist with different agegroup showed significant differences in job stress levels $(P<0.01)$. The job stress score $(36.34 \pm 10.86)$ of pharmacists in 31- to 35-year-old age-group was higher than that of other age-group (28.28 \pm 10.71 in less than 25-yearold age-group and $34.56 \pm 9.23$ in $26-30$-year-old agegroup), suggesting that job stress increased with length of employment. On the other hand, corresponding to length of employment, there was a significant difference in the job stress among young pharmacists with different professional titles. Their job stress scores were $29.88 \pm 10.72$, $35.07 \pm 10.74,36.59 \pm 9.27$, and $39.80 \pm 8.35$ for corresponding assistant pharmacist, pharmacist, pharmacistin-charge, and deputy chief pharmacist, respectively $(P<0.01)$, suggesting deputy chief pharmacists confront

Table 2 Job stress scores of the respondents

\begin{tabular}{ll}
\hline Variable & Job stress scores \\
\hline Gender & \\
Male & $36.46 \pm 11.59$ \\
Female & $34.28 \pm 10.15$ \\
Age & \\
Less than 25 & $28.28 \pm 10.71$ \\
26-30 & $34.56 \pm 9.23$ \\
31-35 & $36.34 \pm 10.86$ \\
Education background & \\
Associate degree and below & $34.82 \pm 9.54$ \\
Bachelor degree & $34.42 \pm 11.00$ \\
Master degree or above & $36.57 \pm 9.15$ \\
Hospital grade & \\
Level 1 & $34.12 \pm 11.36$ \\
Level 2 & $32.43 \pm 12.36$ \\
Level 3 & $35.46 \pm 9.89$ \\
Professional title & \\
Assistant pharmacist & $29.88 \pm 10.72$ \\
Pharmacist & $35.07 \pm 10.74$ \\
Pharmacist-in-charge & $36.59 \pm 9.27$ \\
Deputy chief pharmacist & $39.80 \pm 8.35$ \\
Chief pharmacist & $/$ \\
Specific work post & \\
Dispensing pharmacy & \\
Clinical pharmacy service & $34.98 \pm 10.58$ \\
Pharmacy intravenous admixture services & $36.78 \pm 9.47$ \\
Other work posts & $30.96 \pm 11.58$ \\
\hline & $32.63 \pm 10.46$ \\
\hline
\end{tabular}


more job stress for routine work, as well teaching and research.

\section{Viewpoints of young pharmacists on their profession}

Answers to three questions indicated the viewpoints of the young pharmacists on their profession prospect (Table 3). In general, among 289 respondents, more than $30 \%$ of the young pharmacists did not have long-term career plan for their work. And about $60 \%$ of young pharmacists were troubled or worried about their job future. More than half of young pharmacists will not choose pharmacist as profession a second time.

Specifically, more than $70 \%$ of pharmacists in the 25-30 age-group were troubled or worried about their career future. All deputy chief pharmacists were troubled or worried about the career future.

More than half of young pharmacists in the 31-35 agegroup would not choose pharmacist as occupation again. And more than $60 \%$ of deputy chief pharmacists would not choose the profession of pharmacists any more. All these data suggest that the profession of pharmacists was not a satisfying one for young people under the COVID19 pandemic.

\section{Stress management proposal}

Almost all young pharmacists hoped to improve their professional identity via raising their wages. Half of them hoped that pharmacy managers could organize team activity to release job stress. And about $50 \%$ of young fellows wanted to train or study further in order to master more skills to handle with professional transformation and to adapt the changing COVID-19 pandemic world.

\section{Discussion}

COVID-19 pandemic significantly altered our routine, lifestyle, and stress level across the globe. This study explored the job stress of Chinese young hospital pharmacists during an outbreak of COVID-19 pandemic. The

Table 3 Young pharmacists' options on pharmacist profession prospect issues

\begin{tabular}{|c|c|c|}
\hline Questions & Options & Quantity \\
\hline \multirow{2}{*}{$\begin{array}{l}\text { Do you still have a long-term } \\
\text { career plan for pharmacists } \\
\text { in the pandemic? }\end{array}$} & Yes & $188(65.05 \%)$ \\
\hline & No & $101(34.95 \%)$ \\
\hline \multirow[t]{3}{*}{ How do you see your future? } & Bright and confident & $62(21.45 \%)$ \\
\hline & Feel troubled or worried & $177(61.25 \%)$ \\
\hline & Have not considered & $50(17.3 \%)$ \\
\hline \multirow{2}{*}{$\begin{array}{l}\text { If you had a chance again, } \\
\text { would you still choose } \\
\text { pharmacist as a career? }\end{array}$} & Yes & $126(43.6 \%)$ \\
\hline & No & $163(56.4 \%)$ \\
\hline
\end{tabular}

subjects of survey are young pharmacists who usually have been working for less than 10 years. We believe that if the young fellows are under great pressure during the unusual pandemic, it will have an adverse impact on their future career development.

In the past 5 years, a series of medical reform policies and rational drug use specifications have been issued intensively by the National Health Commission of China. First, the medical insurance payment mode convert (for example, disease diagnosis-related group, DRG) is advanced and currently being applied in medical institution national widely. Generic drugs have been advocated for use by all levels of government. Drug centralized procurement or drug quantity purchase is being executed all over the country [17]. Second, many new practice requirements are proposed to hospital pharmacist, such as controlling the medical expense rise via rational drug use. However, the pharmacist service fee has not yet been implemented despite the appeal for many years in China, meanwhile drug price zero bonus policy in medical institution has been implemented for couple of years. To a certain extent, these policies are absolutely negative bad news for young pharmacists. COVID-19 global pandemic officially declared on March 11, 2020 by the World Health Organization (WHO) furthermore brought about invisible pressure. Many front-line hospital pharmacists cited job stress and fear of the virus infection just like their foreign counterparts [18]. The COVID-19 pandemic is only the last straw to crush young pharmacists. Under this context, it is not a surprise that this survey showed that more than $60 \%$ young hospital pharmacist complained of high job stress and worried their job future during COVID-19 pandemic in China.

Specifically in this survey, we noted that the job stress increased with their age/professional title. The reasons are complex. In China, professional title in the hospital pharmacy has five categories, climbing from the bottom of assistant pharmacist through pharmacist, pharmacistin-charge, deputy chief pharmacist, to the top of chief pharmacist. Pharmacists with different titles usually have different specific work post responsibility and requirement. At the present medical practice environment, there are more performance assessment indicators and more workload for deputy chief pharmacists, however, their income does not match their contribution correspondingly. Deputy chief pharmacists have to bear teaching and research work, as well as publishing papers to get promotion, which are tough pressure for many young pharmacists. A recent survey found that the COVID19 pandemic has increased psychological stress among healthcare workers (including pharmacist) with 10 years or more work experiences in a central hospital in China [19], which is consistent to our results. 
Although our data showed that no specific work post differences in the job stress among young pharmacists in this survey, 190 young dispensing pharmacists of all 289 young fellows poured out a lot of complaints besides the questionnaire investigation. They confessed that most outpatient pharmacies were equipped with automated dispensary systems, but automation does not effectively reduce the working time of dispensing pharmacists. In addition, since outpatient pharmacy is the final stop for hospital process, patients often turn their grievances and anger into complaints and finally vent their anger on the front-line dispensing pharmacist [20]. Young pharmacists have to bear the pressure of tense doctor-patient relationship [21]. In China, during the peak period of outpatient service, dispensing pharmacists are required to dispense in short time as soon as possible without any error. It is a great challenge. They fear being complained by patients [22]. They fear COVID-19 pandemic more and would prefer stay at home on leave without any income.

Therefore, it is of importance for pharmacy managers to help their young fellows in emotion management and release their job stress especially during the COVID-19 pandemic. As $90 \%$ of young pharmacists wish to raise salary, hospital pharmacy managers should advocate legislating for pharmacist service fee. Meanwhile hospital pharmacy managers should give their young fellows more opportunities to day-release course study. In general, the contribution of pharmacists in medical service should be recognized and physical and mental health care should be given simultaneously [23-25].

The study limitation is that job stress is measured using as a self-reported stress level.

\section{Conclusions}

More than half of the young hospital pharmacists feel job stress. Job stress is inevitable. Pharmacy managers should help young fellows to alleviate their job stress and finally improve their professional social identity.

\section{Acknowledgements \\ The authors would like to acknowledge the young pharmacist fellows who participated in this study.}

\section{Authors' contributions \\ JW and JC are co-first authors and contributed equally to this work. FX con- ceptualized the project. JW, JC, MF and YW contributed with data collection. JW and JC contributed equally to data analysis and interpretation. JW, JC and FX contributed with manuscript writing and revision. The final version was read and approved by all authors. All authors read and approved the final manuscript.}

\section{Funding}

This work was supported by the Medicine Guide Program of Shanghai Municipal Science and Technology Commission (grant no. 19411971700), and Shanghai Municipal Clinical Pharmacy Key Discipline Reconstruction Program (grant no. 2018-2020).

\section{Declarations}

\section{Competing interests}

No known competing interest to declare.

\section{Author details}

${ }^{1}$ Fengxian Hospital, Southern Medical University, Shanghai, China. ${ }^{2}$ School of Pharmacy, Shanghai University of Medicine \& Health Sciences, Shanghai, China. ${ }^{3}$ Fengxian Mental Health Center, Shanghai, China.

Received: 27 April 2021 Accepted: 3 August 2021

Published online: 06 August 2021

\section{References}

1. Cao JW, Cai XJ, Zhu YT. Investigation and analysis on pressure sources of pharmacists in central pharmacists of intravenous drug administration. China Rural Med. 2014;22:59-60.

2. Wu XM, Yin T, Wang D, Dai TT, Huang Q. Investigation and strategies on occupation state and mental health of young pharmacists in a tertiary general hospital. Chin J Hops Pharm. 2018;38(22):2373-6.

3. China Daily. Latest on the COVID-19 pandemic. http://www.chinadaily. com.cn/a/202105/30/WS6091e017a31024ad0babbf9e.html. Accessed 30 May 2021.

4. Elbeddini A, Prabaharan T, Almasalkhi S, Tran C. Pharmacists and COVID19. J Pharm Policy Pract. 2020;13:36.

5. Bukhari N, Rasheed H, Nayyer B, Babar ZUD. Pharmacists at the frontline beating the COVID-19 pandemic. J Pharm Policy Pract. 2020;13:8.

6. Luo M, Guo L, Yu M, Jiang W, Wang H. The psychological and mental impact of coronavirus disease 2019 (COVID-19) on medical staff and general public. Psychiatry Res. 2020;291:113190.

7. Yu JY, Jiang B, Han YL, Liu Y. Investigation of the psychological status of the staff in the pharmacy department of a grade A hospital during the coronavirus disease 2019 epidemic. Chin Pharmacet. 2020;29(8):35-8.

8. Chen $Y Z$, Chen XL, Tong RS, Long EW, Li JQ, Xiong X. Construction of the management model of the early psychological preventive medicine under the SARS-CoV-2 epidemic in the pharmaceutical department. Chin J Hosp Pharm. 2020;40(7):734-7.

9. Duan JJ, Li GC, Situ B, Tao JH, Deng X, Wu JY, Zhou T, Zheng ZH, Xu F. Survey of career identity and job satisfaction among young hospital pharmacists in Guangdong province. China Afri J Pharm Pharmacol. 2011;5(3):386-9.

10. Li H. The effect of mental stress on job burnout of clinical pharmacist. Med J Chin People's Health. 2013;25(8):14-5.

11. Shi Y, Xu X, Wang D. Analysis on occupational pressure source of primary hospital pharmacists. Hosp Administ J PLA. 2014;30(3):226-7.

12. Zhao J, Zhang XJ, Du SZ. Factors associated with burnout and job satisfaction in Chinese hospital pharmacists. Medicine (Baltimore). 2020;99(35):e21919.

13. Wang J, Wei JB, He CZ. Occupational stress and countermeasures of licensed pharmacists in pharmaceutical enterprises. J Chin Pharm Industry. 2013;22(2):10-1.

14. Yoo JY, Dutra SVO, Fanfan D, Sniffen S, Wang H, Siddiqui J, Song HS, Bang $\mathrm{SH}$, Kim DE, Kim S, Groer M. Comparative analysis of COVID-19 guidelines from six countries: a qualitative study on the US, China, South Korea, the UK, Brazil, and Haiti. BMC Public Health. 2020;20(1):1853.

15. Li J, Li Z. Differences and similarities in clinical pharmacy practice in China and the United States: a narrative review. Eur J Hosp Pharm. 2018;25(1):2-5.

16. Wang T, Tang HM, Cai QQ, Liu T, Ou BX, Wang RL, Wu JY, Ren JM, Huang WQ, Xiao H, Zhong Y, Lei L. Investigation on working intensity and pressure of outpatient pharmacists based on real time quantified wearable device. Chin J Hosp Pharm. 2017;37(23):2400-4.

17. Lu SH, Li ZM, Xu F. Helping patients accept generic drugs in China. Patient Edu Counsel. 2021;104:45-6.

18. Algunmeeyn A, El-Dahiyat F, Altakhineh MM, Azab M, Babar ZUD. Understanding the factors influencing healthcare providers' burnout during the outbreak of COVID-19 in Jordanian hospitals. J Pharm Policy Pract. 2020;13:53. 
19. Wang N, Li YQ, Wang QX, Lei CH, Liu YY, Zhu SS. Psychological impact of COVID-19 pandemic on healthcare workers in China Xi'an central hospital. Brain Behav. 2021;11(3):e02028.

20. Wu XM, Yin T, Wang D, Dai TT, Huang Q. The front-line workers face hardship in the Pharmacy Dispensing Counter. Chin J Hosp Pharm. 2008;38(22):2373-6.

21. Ma E, Fang M, Xu F. Pharmacist dispense under a doctor-patient tension: how should we deal with? Eur J Hosp Pharm. 2014;21(6):378.

22. Ren JX, Chen J, Jin C. A brief discussion on the psychological status and countermeasures of hospital pharmacists. Chin J Hosp Pharm. 2010;30(23):2036-7.

23. Wang XL, Wei SY. Occupational analysis and incentive mechanism of clinical pharmacists. Chin Hosp Manage. 2004;9:24-5.
24. Zhu SF, Hong MY. Analysis and countermeasures of pharmaceutical staff engagement in tertiary public hospitals in Jiangsu province. Pharm Eval. 2017;14(6):21-30

25. Duan LF, Zhou Q, Liu XX. A survey on the working intensity, fatigue and stress of PIVAS pharmacists in 4 grade III hospitals in Suzhou. Chin Pharmacist. 2020;23(2):391-5.

\section{Publisher's Note}

Springer Nature remains neutral with regard to jurisdictional claims in published maps and institutional affiliations.
Ready to submit your research? Choose BMC and benefit from:

- fast, convenient online submission

- thorough peer review by experienced researchers in your field

- rapid publication on acceptance

- support for research data, including large and complex data types

- gold Open Access which fosters wider collaboration and increased citations

- maximum visibility for your research: over $100 \mathrm{M}$ website views per year

At BMC, research is always in progress.

Learn more biomedcentral.com/submissions 